\title{
Golgi and Ranvier: from the black reaction to a theory of referred pain
}

\author{
Valentina Cani, PhDa \\ Paolo Mazzarello, MD, PhD \\ ${ }^{a}$ C. Mondino National Neurological Institute, Pavia, \\ Italy \\ b Department of Brain and Behavioral Sciences and \\ University History Museum, University of Pavia, \\ Pavia, Italy
}

Correspondence to: Paolo Mazzarello

E-mail: paolo.mazzarello@unipv.it

\section{Summary}

In his brief report on the structure of the gray matter of the central nervous system (1873), in which he described the "black reaction", Golgi noted the ramifications of the axon. This discovery prompted the French histologist Louis Antoine Ranvier, one of the first to try the black reaction outside Italy, to propose an ingenious theory of referred pain in his Traité technique d'histologie. Ranvier suggested that the nerve fibers originating from the irritated area and those coming from the region to which the sensation is referred converge on the same axon and thus the same cell body, causing the spatial dislocation of sensation. This theory of referred pain is a powerful example of the extraordinary clinical-physiological impact of the first of Golgi's neurocytological discoveries.

KEY WORDS: black reaction, Camillo Golgi, Louis Ranvier, ramified axon, referred pain

Golgi, the black reaction and the branching of axons

In 1865 an important book by the German microscopist Otto Friedrich Karl Deiters was published (Deiters, 1865; Shepherd 1991). The volume described studies investigating the histology and anatomy of the nervous system, performed using chromic acid and potassium dichromate as fixatives and carmine as a stain. It was edited and published posthumously (two years after Deiters' death of typhus) by one of his mentors, Max Schultze, a pio- neer investigator of cell theory. The highlights of this work include Deiters' description and beautiful illustrations of the nerve cell (ganglion cell). He maintained that two types of process originated from the cell body: the first was the protoplasmic process, so called because it contained a granular or pigmented expansion of the protoplasm (the term "dendrite" would not be used until 1889, when it was introduced by Wilhelm His); the second was the nerve process or axis cylinder process, which originated from an implantation cone (now called the axon hillock) that did not ramify. The word Achsencylinder was coined by Joseph Rosenthal, a student of Purkinje's, while the term axon was first used by Mihály (Michael) Lenhossék in 1895 following a suggestion by Albrecht (Albert) von Kölliker, who officially introduced the term in 1896.

Deiters' book became widely disseminated and the nerve cell model it proposed soon became well known. However, it was immediately evident that improvements in central nervous system staining technology were needed in order to advance knowledge and understanding of the morphology of nerve cells.

The most important breakthrough in the field of morphological investigation of brain architecture was made in 1873 by Camillo Golgi (Mazzarello 2006, 2010, 2011), at the time chief physician at the Pio Luogo degli Incurabili, a hospital for chronic diseases in Abbiategrasso (about thirty kilometers from Pavia, where Golgi graduated).

Golgi was born on July 7, 1843 in Corteno, a tiny Alpine village in northern Lombardy. His father was a physician (from 1838, the general practitioner in Corteno). Golgi studied at the University of Pavia where he graduated as a medical doctor in 1865. At that time Pavia, a peaceful medieval town on the banks of the river Ticino, was very much like Lombardy's other medieval towns, except for the presence of an ancient university which constituted its geographical and cultural heart. The University of Pavia was famous internationally for the great physicists, mathematicians, men of letters, biologists and medical doctors who had studied and taught there. These included Gaspare Aselli, who discovered lymphatic vessels; Antonio Scarpa, a name that every medical doctor associates with the Scarpa triangle and the Scarpa ganglion of the ear; Alessandro Volta, the inventor of the battery (the voltaic pile); and 
Lazzaro Spallanzani, one of the founders of modern experimental biology. Golgi had direct links with this illustrious history and scientific tradition, as he was taught by Bartolomeo Panizza, a professor of anatomy who was a pupil and a successor of Antonio Scarpa. After his graduation, Golgi became an assistant physician at the San Matteo Hospital, where he worked in the psychiatric clinic headed by Cesare Lombroso (Mazzarello, 2006, 2010). In the free time that his hospital duties allowed him, Golgi attended the Institute of General Pathology where he began to study histological techniques under the direction of Giulio Bizzozero, one of the Italian pioneers of cell biology who would later become famous for his discovery of platelets (Mazzarello et al., 2001).

Needing to find a stable position, in 1872 Golgi took part in and won a competition for a job at the hospital for chronic diseases in Abbiategrasso.

Everything seemed to suggest that, on taking up his position at this small hospital, Golgi's research activity would come to an end. After all, the institution was nearly completely lacking in scientific instruments. Furthermore, the administrative director did not allow funds to be spent on anything not strictly linked to the patients' treatment and healthcare needs. Golgi overcame this difficulty by setting up, in the kitchen of his small flat, a rudimentary laboratory consisting of a microscope and a few other instruments. Here, far from the leading centers of research but true to his vocation and to his teacher of histological techniques, he stubbornly continued his research (Mazzarello, 2006, 2010).

At the beginning of 1873 , Golgi wrote these words to a friend: "I spend long hours at the microscope. I am delighted that I have found a new reaction able to demonstrate, even to the blind, the structure of the interstitial stroma of the cerebral cortex. I let the silver nitrate react with the pieces of brain hardened in potassium dichromate. I have obtained magnificent results and hope to do even better" (Mazzarello, 2010).

This is the first recording of his discovery (or invention) of the "black reaction", nowadays known as "Golgi impregnation" or "Golgi staining", which constituted a breakthrough in brain structure research. Indeed, this methodological contribution earned Golgi the Nobel Prize in Physiology or Medicine in 1906.

The "black reaction" consisted of a first phase of "hardening" of the tissue in potassium dichromate followed by impregnation of the nervous elements by silver nitrate. This procedure resulted in silver chromate precipitate randomly filling the nerve cells and their processes in their entirety. In this way, the silhouette of the nerve cell appeared in all its morphological complexity with all its ramifications, which could be followed and analyzed even at a great distance from the cell body. The great advantage of this technique is that, for reasons that are still unknown, the precipitate of silver chromate selectively stains, in black, only a small proportion of nerve cells (usually from 1 to $5 \%$ ), and completely spares the others, allowing the individual elements to emerge from the "nervous puzzle".

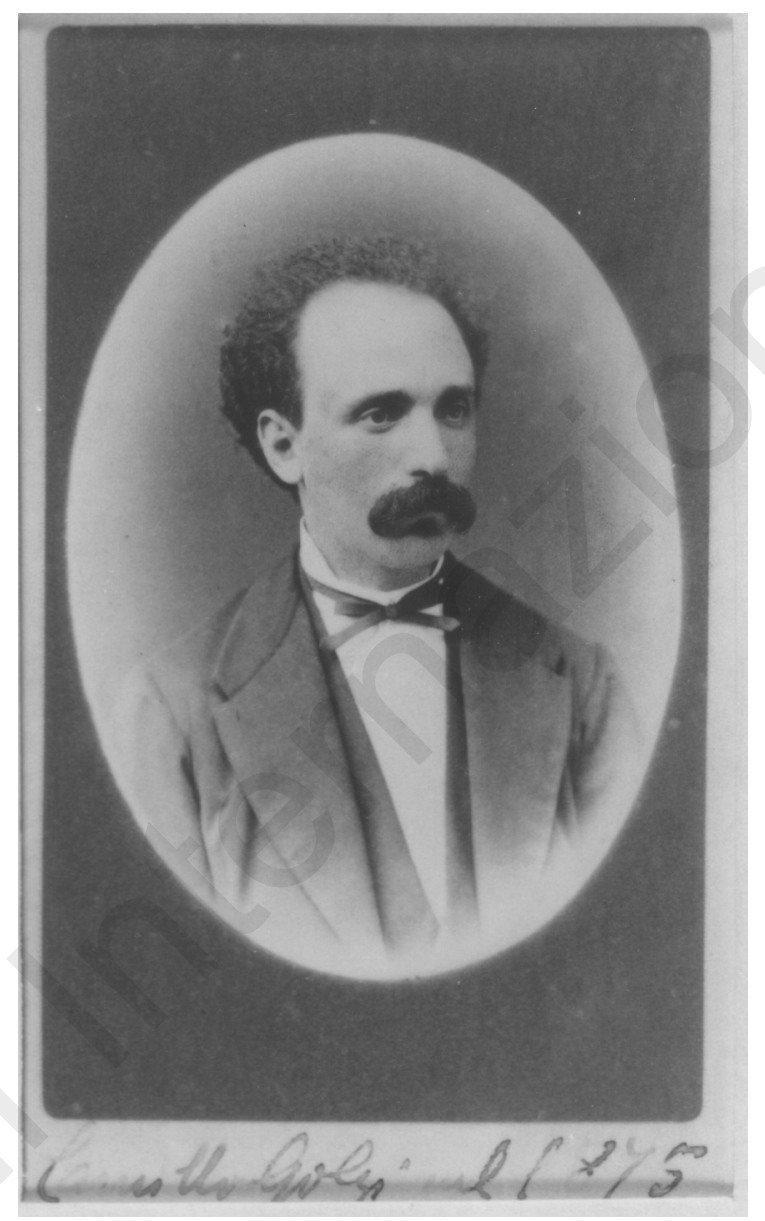

Figure 1 - Camillo Golgi in 1875 (Golgi Museum, University of Pavia).

Among the remarkable advances achieved by Golgi through the application of his black reaction were the ones obtained in the field of neurocytology. The young neurobiologist was able to observe and describe various morphological variants of nerve cells and to ascertain that ganglion cells always contained an axon. One of Golgi's most important discoveries, however, was his finding - contrary to what Deiters believed - that prolongations branched off from the cylinder axis (axon) giving rise to "a great number of ramifications, which also branch out, producing a complex system of threads diffused throughout the gray matter of the brain" (Golgi, 1873). This was one of Golgi's most enduring contributions to neurocytology.

Moreover, Golgi analyzed several regions of the nervous system in detail, providing beautiful illustrations of them, and described many new cell types, including the so-called Golgi cells of the cerebellum (Galliano et al., 2010).

His discovery/invention of the black reaction sparked a true scientific revolution which allowed the morphology and the basic architecture of the cerebral tissue to be shown in all their complexity. Golgi's investigations were a remarkable contribution to the advancement of 


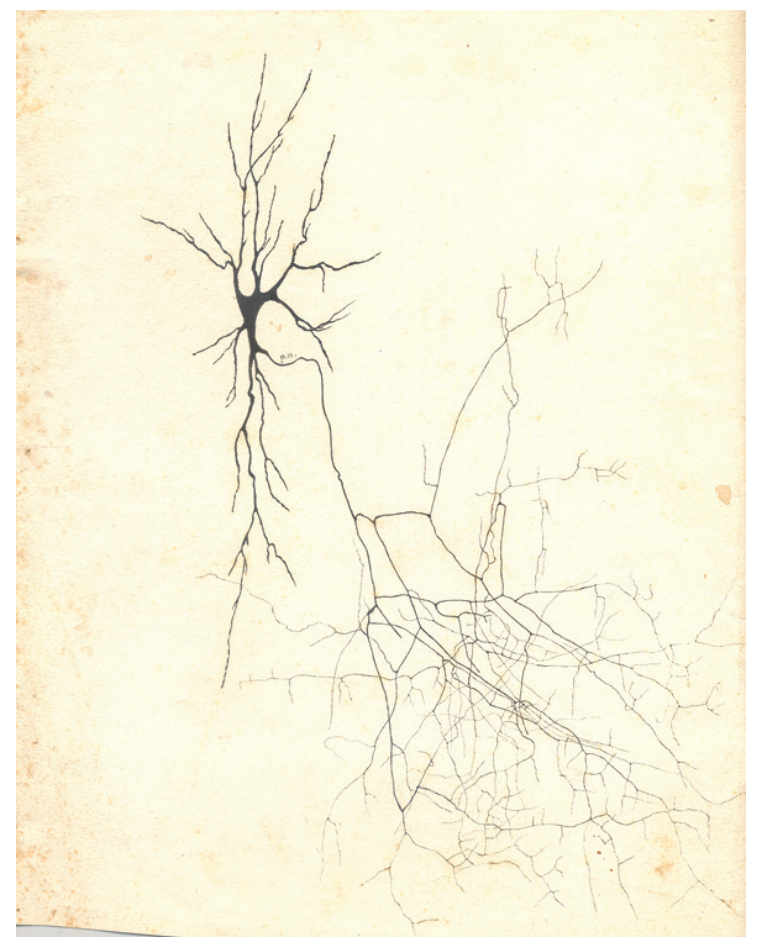

Figure 2 - A nerve cell drawn by Camillo Golgi (Museum for the History of the University of Pavia).

knowledge on the structural organization of the nervous system.

On 2 August 1873, Golgi published, in the Gazzetta Medica Italiana-Lombardia (Italian Medical GazetteLombardy), a first brief description of the method. The article was entitled Sulla struttura della sostanza grigia del cervello (On the structure of the gray matter of the brain) (Golgi, 1873). Subsequently he published works on the anatomy of the cerebellum and the olfactory bulbs, and on the histological alterations observed in a case of chorea (Mazzarello, 2006, 2010). In 1876 he was appointed professor of anatomy at the University of Siena, where he remained for only a few months. He was subsequently appointed full professor in Pavia (first of histology and then of general pathology). This is where he performed all his subsequent scientific activity and further developed his career.

Golgi's first publications on the structure of the central nervous system, based on his application of the black reaction, did not gain wide international recognition. However, one the few histologists who did notice the method was a collaborator of Claude Bernard, the French histologist Louis Antoine Ranvier, who held the chair of general anatomy at the Collège de France (Jolly, 1922; Appel, 1975; Barbara, 2006, 2007; Boullerne, 2011; Belloni, 1980).

\section{Golgi and Ranvier}

September 1876 found Golgi, together with histologists Giuseppe Vincenzo Ciaccio and Salvatore
Richiardi, in Viareggio, a small seaside resort in Tuscany, which attracted zoologists and physiologists interested in marine biology. There, they were joined by Franz Christian Boll, another pupil of Max Schultze, who taught comparative anatomy and physiology at the University of Rome and used to stay at the seaside to study the retina of marine animals and the electric organ of the torpedo ray, and also by Louis Ranvier, together with his assistant factotum Édouard Weber (Belloni, 1980; Mazzarello, 2006, 2010; Finger and Piccolino, 2011).

This group of histologists had gathered in the hope of conducting some research together (Boll wrote to Emil du Bois Reymond, 1818-1896, that his Italian colleagues were "extremely kind"), but there proved to be too many of them and they ended up hindering each other's efforts (Belloni, 1980). It is likely that Golgi showed Ranvier some neurohistological preparations stained with the black reaction and the French scientist may well have been one of the first to try the method outside Italy. From Ranvier's teachings in Paris, between 1880 and 1885, the Spanish histologist and psychiatrist Luis Simarro Lacabra became acquainted with Golgi's method, taking it back with him to Spain in 1887 (Ramón y Cajal, 1989; Fernandez et al., 2001). It was at his house, in calle del Arco de Santa Maria, that Santiago Ramón y Cajal was introduced to Golgi's method, an event that changed Cajal's scientific life. When Simarro Lacabra showed him a slide stained with the black reaction his surprise and emotion were enormous. The microscopic sight of a nerve cell with

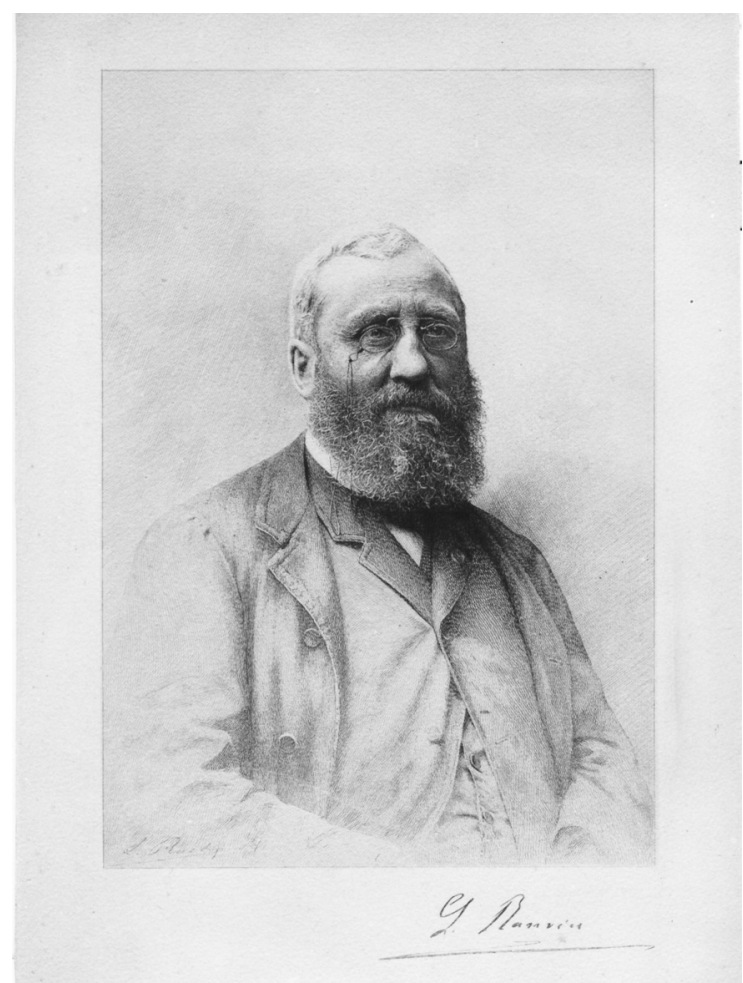

Figure 3 - Louis Antoine Ranvier (Courtesy of Dr Jean-Gaël Barbara). 
all its processes was a sort of revelation for Ramón y Cajal. From that moment on he decided to devote his scientific work to study of the nervous system using the powerful tool invented by Golgi.

When Ranvier met Golgi in 1876, he was already famous for some essential improvements to the histological techniques and for some important observations on normal and injured nerve fibers. Much of his methodological expertise was gathered in his Traité technique d'histologie (Technical treatise on histology), issued in installments starting from 1875 (Ranvier, 1875), which gained wide international recognition: in 1887, Santiago Ramón y Cajal described it as his own "technical Bible" (Ramón y Cajal, 1989).

In his treatise, Ranvier (1875) observed that with the black reaction method: "ganglion cells, examined in transmitted light, appear completely black; they are opaque. Their extensions, as black as their bodies, are colored in a variable length from their origin. Sometimes the color stops abruptly; they seem cut off. Nothing is more irregular than the distribution of the deposition of silver chromate. Sometimes the preparations are of remarkable beauty; but, frequently, the deposition becomes irregular. Some ganglion cells are stained, while others are spared and [the reaction] has more or less completely invaded the blood vessels and the glial cells that, here and there, form features like

RAITÉ TECHNIQUE

\section{D'HISTOLOGIE}

Figure 4 - Title page of the Traité technique d'histologie (Golgi Museum, University of Pavia). tufts of grass". Thus, Ranvier felt that the Golgi method was not reliable enough to demonstrate with accuracy the fine structure of the nerve cells and favored instead metal impregnation with silver nitrate and gold sublimate (Boullerne, 2011).

\section{The referred pain theory of Ranvier}

In spite of his technical criticisms of the black reaction, Ranvier was fascinated by Golgi's discovery that the axon is ramified. On the grounds of this discovery, he elaborated an ingenious theory to explain what is now known as "referred pain", a term probably introduced by the British neurologist Henry Head (Breathnach, 1994). It was known that a pain can sometimes be a felt in a region distant from its area of origin. One of the first attempts to theoretically explain this phenomenon was made in the eighteenth century by the Scottish anatomist John Hunter, who interpreted the pain originating in an organ and felt in a distant area on the surface of skin as a mistaken perception. He wrote that "A simple sensation in the mind of a local disease in the body which does not correspond with the seat of the disease itself has, I believe, been always referred to the principle of sympathy. Thus, sensation of pain in the shoulder from disease in the liver has been always supposed to arise from the shoulder sympathizing with the liver. The sensation of the glans penis from a disease or irritation in the bladder has been referred to the same cause. But I believe it is a delusion in the mind; for the nerves of the part are not the seat of the disease; and irritation could not communicate to the mind the sensation of pain in the part affected, excepting they (the nerves) take on the same action, which they must do when they produce the sensation of pain of that part" (Hunter, 1837, 1839; Breathnach, 1994). He then advanced a schematic explanation based on a sort of "convergence" principle to account for the dislocation of sensation referred to a part of the body different from the one affected. He hypothesized that nerves could converge in the body or connect in the brain in such a way as to create a misrepresentation of the localization of the sensation. However, Hunter's hypothesis remained substantially unknown to the neurological literature.

Taking into consideration Golgi's discovery of the ramification of the axon, Ranvier found a physical basis to explain such a convergence mechanism able to account for the referred pain phenomenon. In the Traité technique d'histologie he proposed that the nerve fibers originating from the irritated area and those originating from the region to which the sensation is referred converge along the ramified axon of the same nerve cell body, causing the spatial dislocation of the sensation. He wrote: "Golgi's observations on the division of axon extensions of the brain and the cerebellum ganglion cells account for some phenomena of sensitivity that everyone can observe on himself, phenomena that consist of the tingling sensation or pain that is experienced in some parts of the skin or mucous membranes when a different region of the body sur- 


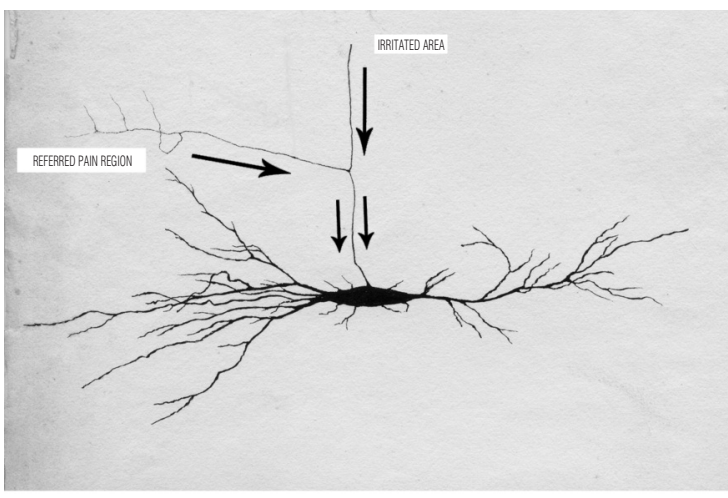

Figure 5 - Ranvier's referred pain interpretation. Reconstruction from an original drawing by Golgi (modified) (Museum of the History of the University of Pavia).

face is irritated. This phenomenon seems to result from the fact that two nerve fibers, one from the irritated area, the other from the region to which the sensation is referred, reach the same nerve cell. With Deiters' older data, according to which the axon extension remained undivided, it was impossible to see how this phenomenon could occur" (Ranvier, 1875).

Ranvier thus emphasized that the previous concept of the non-ramified axon (according to Deiters) could not shed light on the phenomenon of referred pain. On the contrary, on the basis of Golgi's observation, the French scientist proposed a mechanism able to explain it at cellular level. Since he was one of the first to try the black reaction, a few years after its discovery/invention, he was also a pioneer, probably the first, in suggesting a new principle of nervous organization based on the method. Moreover, it is interesting to note that in proposing his theory, Ranvier, compared with Golgi, hypothesized an entirely different function for the ramifications of the axons, thus demonstrating his remarkable scientific autonomy. His theory of referred pain is a very significant example of the clinical-physiological impact of the first of Golgi's neurocytological and neuroanatomical discoveries. After Ranvier, other developments led to the modern concept of referred pain, linked primarily with the names James Ross, William Allen Sturge, Henry Head and James Mackenzie (Breathnach, 1994; Ross, 1887; Sturge, 1888; Head, 1893; Mackenzie, 1893; Rey, 1995), and now interpreted according to the "convergence projection theory" (Ruch, 1949), which postulates the convergence of afferent visceral fibers into the spinal somatic sensory neurons which give origin to the spinothalamic tract.

\section{References}

Appel TA (1975). Ranvier, Louis-Antoine. In: Gillispie CC (Ed.) Dictionary of Scientific Biography. Vol. 11. New York, Charles Scribner's Sons, pp. 295-297.
Barbara JG (2007). Louis Ranvier (1835-1922): the contribution of microscopy to physiology and the renewal of French general anatomy. J Hist Neurosc 16: 413-431.

Barbara JG (2006). Louis Antoine Ranvier (1835-1922). J Neurol 253: 399-400.

Belloni L (1980). Franz Boll, scopritore della porpora retinica. Memorie dell'Istituto Lombardo - Accademia di Scienze e Lettere, Classe di Scienze Matematiche e Naturali, Memoria 27: 315-437.

Boullerne Al (2011). Neurophysiology to neuroanatomy: the transition from Claude Bernard to Louis Antoine Ranvier. Arch Ital Biol 149 (Suppl): 38-46.

Breathnach CS (1994). John Hunter and pain referred. J R Soc Med 87: 786-789.

Deiters OFK (1865). Untersuchungen über Gehirn und Rückenmark des Menschen und der Säugethiere (edited by M. Schultze). Braunschweig, Vieweg.

Fernandez N, Breathnach CS (2001). Luis Simarro Lacabra (1851-1921): from Golgi to Cajal through Simarro, via Ranvier? J Hist Neurosci 10: 19-26.

Finger S, Piccolino M (2011). The Shocking History of Electric Fishes. From Ancient Epochs to the Birth of Modern Neurophysiology. New York, Oxford University Press.

Galliano E, Mazzarello P, D'Angelo E (2010). Discovery and rediscovery of Golgi cells. J Physiol 588: 3639-3655.

Golgi C (1873). Sulla struttura della sostanza grigia del cervello (comunicazione preventiva). Gazzetta Medica Italiana Lombardia 33: 244-246.

Head H (1893). On disturbances of sensation with especial reference to the pain of visceral disease. Brain 16:1-133.

Hunter J (1839). Lectures on the Principles of Surgery. Philadelphia, Haswell, Barrington and Haswell.

Hunter J (1837). Lectures on the principles of surgery: delirium - dreams. London Medical and Surgical Journal 1:523528.

Jolly J (1922). Louis Ranvier (1835-1922): notice biographique. Archives d'Anatomie Microscopique 19:1-72.

Mackenzie J (1893). Some points bearing on the association of sensory disorders and visceral disease. Brain 16: 321354.

Mazzarello P (2011). The rise and fall of Golgi's school. Brain Res Rev 66:54-67.

Mazzarello P (2010). Golgi. A Biography of the Father of Modern Neuroscience (transl. Badiani A, Buchtal H). New York, Oxford University Press.

Mazzarello P (2006). II Nobel dimenticato. La vita e la scienza di Camillo Golgi. Turin, Bollati Boringhieri.

Mazzarello P, Calligaro AL, Calligaro A (2001). Giulio Bizzozero: a pioneer of cell biology. Nat Rev Mol Cell Biol 2:776-781.

Ramón y Cajal S (1989). Recollections of My Life (transl. Horne Craigie E, Cano J). Cambridge (Mass.), The MIT Press.

Ranvier L (1875). Traité technique d'histologie. Paris, Savy.

Rey R (1995). History of Pain. Cambridge (Mass.) - London, Harvard University Press.

Ross $\mathrm{J}$ (1887). On the segmental distribution of sensory disorders. Brain 10:333-361.

Ruch TC (1949). Visceral sensation and referred pain. In: Fulton JF (Ed.) Howell's Textbook of Physiology. Philadelphia, Saunders, pp. 385-401.

Shepherd GM (1991). Foundations of the Neuron Doctrine. New York, Oxford University Press.

Sturge WA (1888). The phenomena of angina pectoris, and their bearing upon the theory of counter-irritation. Brain 5:492510. 